\title{
The Role of Education in Stimulating Economic Development in the Framework of Europe 2020 Strategy: Evidence from South-Eastern Europe
}

\author{
Monica Raileanu Szeles ${ }^{1}$, Ileana Tache ${ }^{2}$
}

\begin{abstract}
:
A new model of economic development focused on the encouragement of smart, inclusive and sustainable economic growth is the core of the Europe 2020 strategy. Education is widely acknowledged as being a key factor leading to economic growth and economic development, in the long term. But the impact of different kind of achievements in education on growth has little empirical evidence, especially when examining the South-Eastern European countries.
\end{abstract}

This paper analyses the role played by different types of educational achievements, aggregated at the macroeconomic level, beside a set of other potential socio-economic drivers, on the economic growth and quality of life, in the South Eastern Europe, based on the Eurostat panel dataset. A number of panel data regression models using the GMM and FGLS estimators allow answering our research questions.

Our empirical results indicate what policy measures are the most effective to target both the economic growth and quality of life.

Keywords: Europe 2020, education, economic development

JEL Code: 125.

\footnotetext{
${ }^{1}$ Transilvania University of Brasov, Romania

${ }^{2}$ Professor Transilvania University of Brasov, Romania
} 


\section{Background}

Education has been extensively addressed in the economic literature as a key factor of economic growth. But the role of education has slightly increased in recent years, together with the redefinition of economic growth in the framework of Europe 2020 Strategy. In the new perspective, the economic growth must be smart, inclusive and sustainable in order to generate long term benefits for the entire community. Not only achieving high growth rates is important for the national economies, but especially redistributing growth to all social categories, as well as promoting innovation and technology as main drivers of growth. In this context, education could be seen as a bridge between economic growth, technological progress, low social inequality and sustainability. This approach could therefore give insights to the main important drivers of economic growth, when economic growth is associated to a better quality of life, trust in European institutions and lower poverty risk.

Education stays in the core of Europe 2020 Strategy (European Commission, 2010). EU wants to become a smart, sustainable and inclusive economy (see Box 1). These are three mutually reinforcing priorities that should help the EU and the member states deliver high levels of employment, productivity and social cohesion.

Box 1: The three priorities of Europe 2020 Strategy

- Smart growth: developing an economy based on knowledge and innovation

- Sustainable growth: promoting a more resource efficient, greener and more competitive economy

- Inclusive growth: fostering a high-employment economy delivering social and territorial cohesion

Education is primarily linked to the first priority of smart growth. According to Europe 2020 Strategy, smart growth means strengthening knowledge and innovation as drivers of the future growth. This requires improving the education quality, strengthening the resources performance, promoting innovation and knowledge transfer throughout the Union. Europe needs smart growth because its recent lower rhythm of growth is largely due to a productivity gap caused in part by insufficient investment in education, $\mathrm{R} \& \mathrm{D}$ and innovation, as illustrated in Box 2.

\section{Box 2: Shortcomings of the EU educational system}

- Spending on education and training is decreasing or stagnating

- Some $25 \%$ of European school children have poor reading skills;

- Too many young people leave education/training without qualifications;

- The skills of Europe's working-age population are not in line with labor market needs and requirements (according to new findings from the OECD's Survey of Adult Skills (PIAAC); 
- There are remaining barriers due to the myriad of existing diplomas, certificates and qualifications; despite the existence of a large number of policies and instruments, there still remain obstacles for individuals to move between countries, across different education sub-systems, and from education to work;

- The worlds of work and education are not closely linked - making difficult to curb or prevent youth unemployment (one of Europe's most pressing problems);

- Under a third of Europeans aged 25-34 have a university degree (as compared to $40 \%$ in the US and over $50 \%$ in Japan);

- European universities rank poorly in global terms - only 2 in the world top 20 (see Shanghai index (ARWU)).

In order to solve these problems, some important targets were established by the Europe 2020 Strategy (see Table 1). 


\section{Table 1: Targets in Education and Training}

\section{Targets in education and training}

\begin{tabular}{|c|c|c|c|c|c|}
\hline & & & & Current & Target \\
\hline \multirow{2}{*}{ 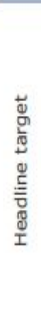 } & 1 & $\begin{array}{l}\text { Early leavers from } \\
\text { education and training }\end{array}$ & $\begin{array}{l}\text { The share of the population aged } 18-24 \text { fulfilling the following } \\
\text { two conditions: (1) the highest level of education or training } \\
\text { attained equals International Standard Classification of } \\
\text { Education (ISCED) level } 0,1,2 \text { or } 3 \text { c short; ( } 2 \text { respondents } \\
\text { declared not having received any education or training in the } \\
\text { four weeks preceding the survey. Data comes from the EU } \\
\text { Labour Force Survey. }\end{array}$ & $12.7 \%(2012)$ & Below $10 \%(2020)$ \\
\hline & 2 & $\begin{array}{l}\text { Tertiary education } \\
\text { attainment }\end{array}$ & $\begin{array}{l}\text { The share of the population aged } 30-34 \text { years who have } \\
\text { successfully completed university or university-like (tertiary- } \\
\text { level) education that equals International Standard } \\
\text { Classification of Education (ISCED) level } 5 \text { or } 6 \text {. Data comes } \\
\text { from the EU Labour Force Survey. }\end{array}$ & $35.7 \%(2012)$ & At least $40 \%$ (2020) \\
\hline \multirow{4}{*}{ 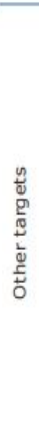 } & 1 & $\begin{array}{l}\text { Early childhood } \\
\text { education and care }\end{array}$ & $\begin{array}{l}\text { The share of the population aged } 4 \text { to the age when the } \\
\text { compulsory education starts who are participating in early } \\
\text { education. Data comes from the UOE data collection. }\end{array}$ & $93.2 \%(2011)$ & $95 \%(2020)$ \\
\hline & 2 & $\begin{array}{l}\text { Achievement in reading, } \\
\text { maths and science }\end{array}$ & $\begin{array}{l}\text { The share of } 15 \text {-year-olds failing to reach Level } 2 \text { in reading, } \\
\text { mathematics and science as measured by the OECD's } \\
\text { Programme for International Student Assessment (PISA). }\end{array}$ & $\begin{array}{l}\text { Reading: } 19.6 \%(2009) \\
\text { Maths: } 22.2 \%(2009) \\
\text { Science: } 17.7 \%(2009)\end{array}$ & $15 \%(2020)$ \\
\hline & 3 & $\begin{array}{l}\text { Employment rate of } \\
\text { recent graduates }\end{array}$ & $\begin{array}{l}\text { The share of employed people aged 20-34 having successfully } \\
\text { completed upper secondary or tertiary education } 1 \text { to } 3 \text { years } \\
\text { before the reference year of the survey and who are no longer } \\
\text { in education or training. Data comes from the EU Labour Force } \\
\text { Survey. }\end{array}$ & $75.7 \%(2012)$ & $82 \%(2020)$ \\
\hline & 4 & $\begin{array}{l}\text { Adult participation in } \\
\text { lifelong learning }\end{array}$ & $\begin{array}{l}\text { The share of the population aged } 25-64 \text { who stated that they } \\
\text { received formal or non-formal education or training in the four } \\
\text { weeks preceding the survey. Data comes from the EU Labour } \\
\text { Force Survey. }\end{array}$ & $9.0 \%(2012)$ & $15 \%(2020)$ \\
\hline
\end{tabular}

As Table 1 indicates, the Europe 2020 Strategy sets out a twofold headline target on: a) early school leaving and b) tertiary education attainment, to be reached by 2020 .

a) The share of early school leavers is to be decreased to below $10 \%$. In 2012, this percentage was $12.7 \%$, lower than the previous year $(13.4 \%)$. Leaving school prematurely makes of course difficult to find employment.

b)

c) The EU is making progress towards the target to increase tertiary education attainment to $40 \%$. At present, it stands at $35.7 \%$, up from $34.5 \%$ the previous year. However, the quantitative increase should be combined with higher education quality.

The European Commission (2016) coordinated an interesting study on the potential of education to cause macroeconomic imbalances and negative spillovers. The main goal of this study was to demonstrate that sustained or widening differences between the performances of educational systems within the EU may contribute - via labor 
market outcomes and subsequently through a range of wider economic impacts - to the emergence or deepening of macroeconomic imbalances.

The case of South-Eastern European countries discussed in our paper reinforces the above mentioned conclusions. The accompanying empirical findings and modelling work of the quoted study are robust and strong enough to convince that looking systematically at the relative performance of education systems is useful to identify potential causes of macroeconomic imbalances.

Education is indeed crucial for both economic and social progress and can promote equity, social inclusion and cohesion. Better educational levels help employability and progress in increasing the employment rate helps to reduce poverty.

Our paper investigates the impact of education (secondary and tertiary), beside other variables, on a set of macroeconomic variables that we consider indicative for economic development within the EU area. The economic development envisages here dimensions such as economic growth, poverty risk, quality of life and confidence in the European Parliament.

The condition to achieve the smart, inclusive and sustainable economic growth is to not worsen the quality of life, to not increase the poverty risk or to not reduce the confidence in the European institutions, as a price for a "glorious" economic growth pattern. More specifically, the paper tries to find out whether there is possible to target together economic, social and political aims by national policy measures within the EU-27 area.

This approach could therefore give insights to the main important drivers of economic growth, when economic growth is associated to a better quality of life, trust in European institutions and lower poverty risk.

The paper is structured in 4 sections. The first section is the background introduction, the second section explains the data and variables used in the paper, the third section presents the methodology and the empirical analysis, being therefore divided into two subsections, while the last section concludes and discusses the results and their policy implications, making also reference to other studies of the relevant literature.

\section{Data and Variables}

The main objective of our paper is to assess the impact of education on economic growth as well as on a set of indicators on the quality of life, poverty risk and trust in the European institutions, based on Eurostat data running from 2003 to 2011. Only the EU-27 countries have been included into the analysis, because there are a lot of missing values in the case of Croatia. 
Even though the impact of education on economic growth is the core of our study, additional dependent variables, i.e. indicators of the quality of life, are added because, as the Strategy 2020 underlines, not any type of economic growth should be of interest for the European economies, but that particular economic growth that enables citizen having a high standard of living.

Two education variables have been selected from the Eurostat dataset, i.e. the secondary and tertiary education attainments. Beside the education variables, other explanatory variables are included in the empirical analysis: unemployment, the Gini coefficient of income inequality, the social protection expenditure and the labour market policy expenditure. They are aggregated at the EU national levels.

The dependent variables are: economic growth, the confidence in the European Parliament, the self-assessment of health status, the inability to make ends meet, the inability to face unexpected expenses and poverty risk. The first variable of interest is the economic growth, but the rest of dependent variables are also important because they reshape the concept of economic growth in line with the Strategy Europe 2020.

Together, all dependent variables reflect the stage of economic development in the EU that encompasses not only economic indicators, but also social and political ones. All variables are taken from the Eurostat dataset, and only some of them have been recorded as to be more indicative for the purpose of our analysis. The selfassessment of health status has been recorded into two variables (bad health or not). The same technique has been applied in the case of variables: the inability to make ends meet, and the inability to pay unexpected expenses. The summary statistics of all dependent and explanatory variables of our study are presented in Table 2.

Table 2: Summary statistics

\begin{tabular}{|l|l|l|l|l|}
\hline Variable & Mean & St. dev. & Minimum & Maximum \\
\hline Economic growth & 1.62 & 4.11 & -16.3 & 12 \\
\hline Confidence in European Parliament & 55.55 & 10.27 & 18 & 77 \\
\hline Bad health & 10.43 & 4.86 & 2.6 & 22.1 \\
\hline Ends meet & 26.36 & 16.79 & 5.5 & 71.2 \\
\hline Unexpected expenses & 35.46 & 15.64 & 7.9 & 80.4 \\
\hline Poverty risk & 15.35 & 3.81 & 8.6 & 25.7 \\
\hline Secondary education & 31.79 & 13.62 & 13.9 & 78.1 \\
\hline Tertiary education & 21.61 & 6.85 & 7.9 & 33.7 \\
\hline Unemployment & 8.17 & 3.90 & 2.3 & 24.8 \\
\hline Gini & 29.22 & 3.96 & 22 & 39.2 \\
\hline Social protection & 23.13 & 5.62 & 11.27 & 33.77 \\
\hline Labour expenditure & 1.50 & 1.01 & 0.14 & 4.36 \\
\hline
\end{tabular}

Source: Eurostat data, 2003-2011. 
The summary statistics presented in Table 1 show a very large economic and social heterogeneity at the EU-27 level. Running the analysis separately for different subgroups of countries (e.g. NMS and OMS) is not possible here because of the short number of observations into our dataset.

However, the degree of heterogeneity varies from one variable to another. For instance, the economic growth and the two subjective variables of the quality of life (inability to make ends meet and inability to face unexpected expenses) are among the variables of highest heterogeneity, while the poverty risk and subjective assessment of health exhibit a lower heterogeneity.

Figure 1 and Figure 2 present the dynamics of education variables from 2003 to 2011. The growth patterns present major differences, especially when comparing the aggregated NMS and OMS attainments. Fig.1 indicates a continuous decrease of secondary education attainments from 2003 to 2011, for both the NMS and OMS. The decrease is much slower in the case of OMS, which suggests a more stable situation. 
Figure 1: The dynamics of secondary education attainments in the NMS versus OMS
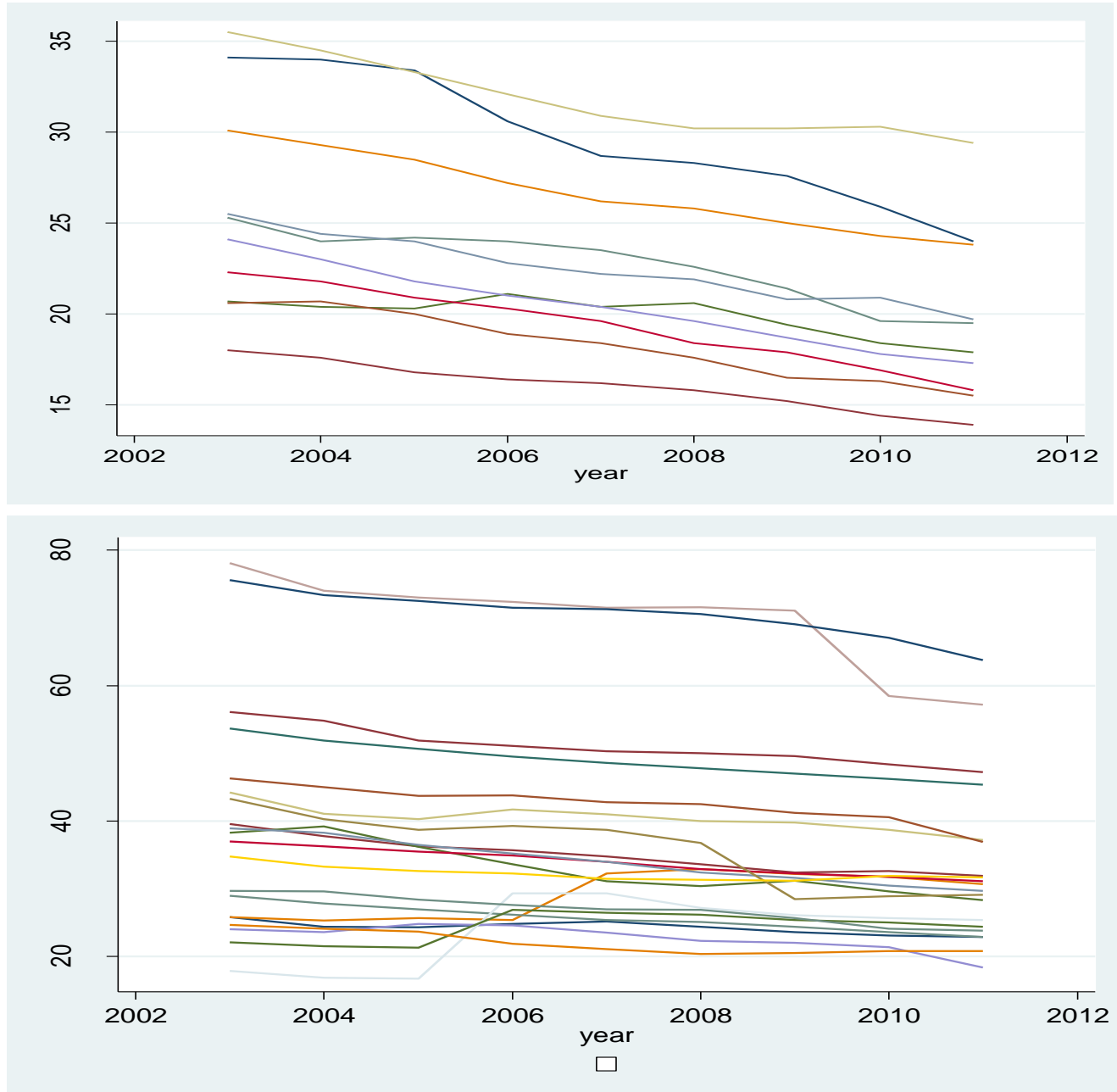

In Figure 2 the tertiary education attainments significantly improve in both the NMS and OMS at the same relatively pace for both groups of countries. However, the progress is more remarkable in the case of NMS, where the dynamic of the tertiary education attainments is only positive across years. This suggests the deficit of higher education in the NMS that persisted many years after the failure of the centralized economy. 
The Role of Education in Stimulating Economic Development in the Framework of Europe 2020 Strategy: Evidence from the South-Eastern Europe

62

Figure 2: The dynamics of tertiary education attainments in the NMS versus OMS
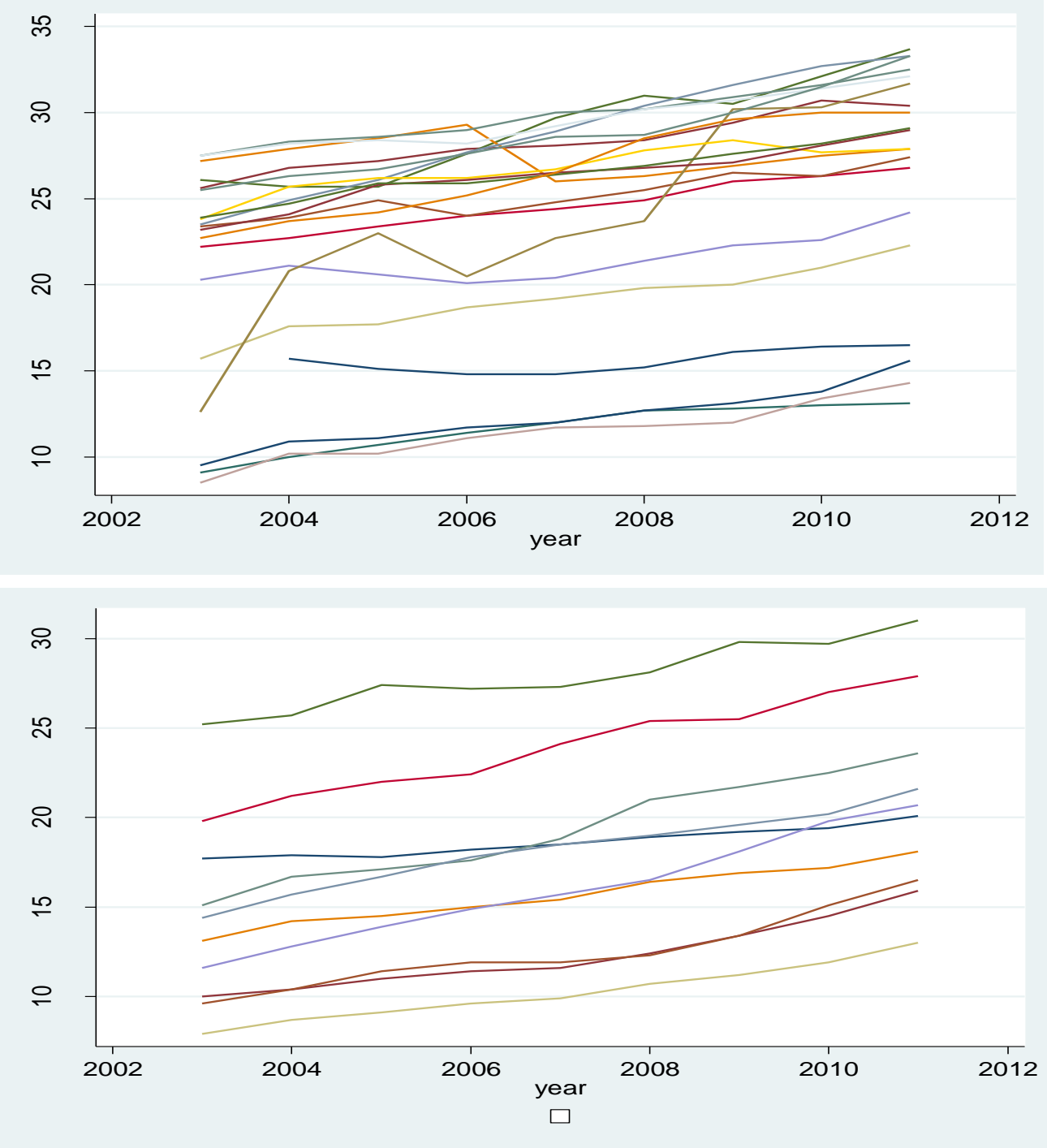

Another variable of interest in our empirical study is the confidence in the European Parliament. Even though apparently this indicator is far away from directly being suggestive for the quality of life, it could give valuable insights into the trust of European citizen in the European institutions. This is indirectly related to the quality of life in the sense that a strong confidence could be fed up by good governance that further should result, inter alia, in a better quality of life.

The confidence in the European Parliament has a fluctuant dynamic and follows a decreasing pattern at the level of both the OMS and NMS. The volatility is more pronounced in the case of the NMS, where the decrease is also sharper. This is not 
surprising as the move from a centralized economy to a free market, as well as the economic difficulties met in the process of the European integration, have eroded the citizens' trust in the European institutions.

Figure 3: Confidence in the European Parliament in the NMS versus OMS

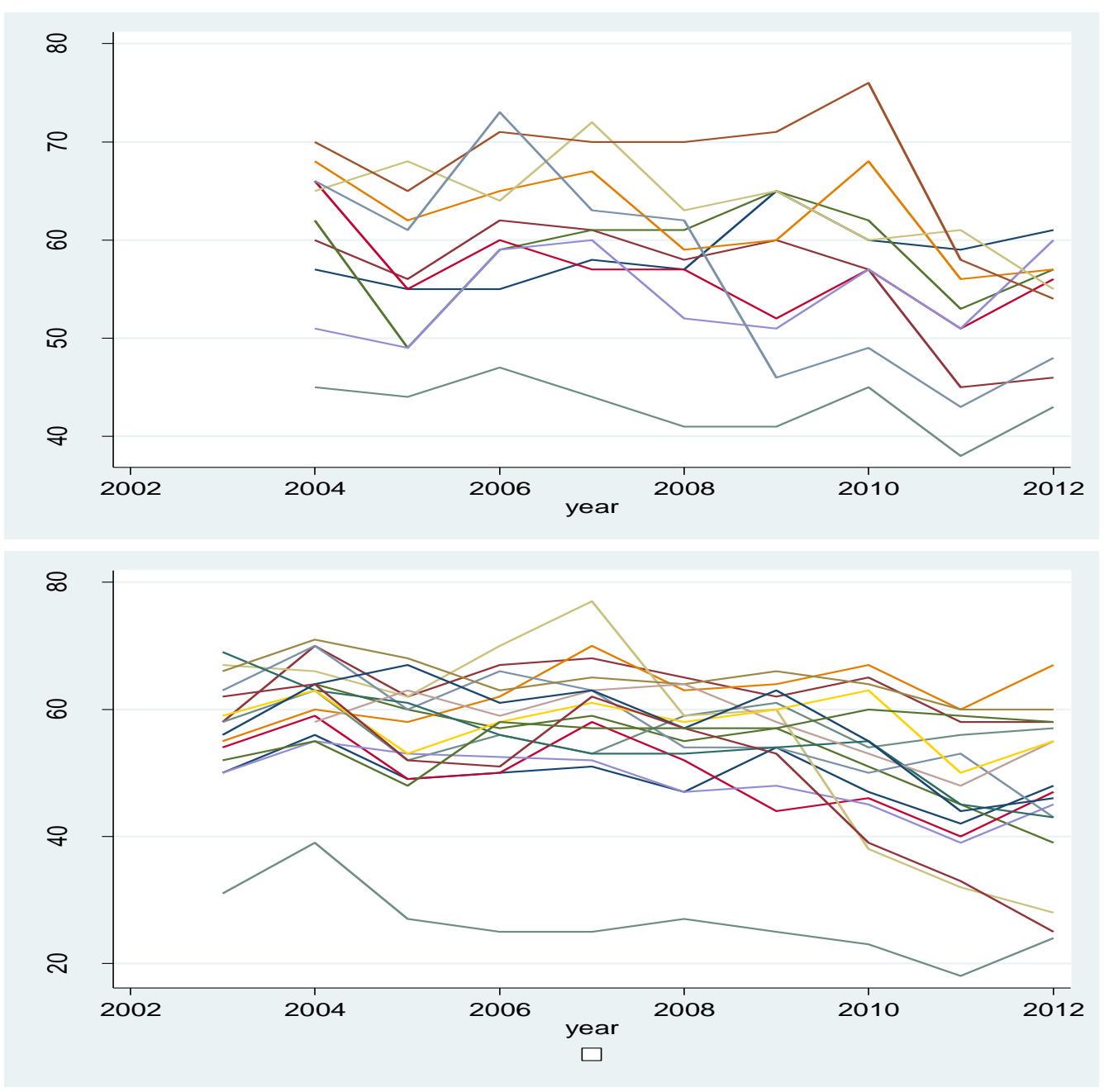

\section{Methodology and empirical analysis}

\section{Methodology}

The panel data regression models represent the econometric technique used to comparatively examine the impact of education, along with other explanatory variables, on economic growth and also on a number of indicators of quality of life, poverty and institutional trust. Six panel data regression models are run using 
different estimators, according to the type of the dependent variable and to the relationship that it has with the set of explanatory variables.

The main dependent variable is the economic growth. When studying its determinants, the endogeneity in relation to the explanatory variables, the heteroskedasticity as well as the the serial correlation could be a matter of concern. The endogeneity is probably the most important problem that should be first addressed, because in case that this problem is confirmed by data, instrumental variable regressions should be used. In the presence of endogeneity, the Ordinary Least Squares (OLS) is biased. Although the endogeneity and the fixed-effects problems are generally instrumented by the Two-Stage Least Squares (2SLS), in the presence of weak instruments, the fixed-effects IV estimators could be biased and other estimators should be used.

When both heteroskedasticity and endogeneity are confirmed, the 2SLS and OLS are not asymptotically efficient, and in this case the GMM estimator is preferred because it is more efficient. Moreover, when the panel datasets are often suspected to be affected by serial correlation in the error terms, the GMM estimator could be more efficient than the 2SLS.

In the regression model (1) reported in Tab.1, all the endogeneity, heteroskedasticity and serial correlation are found to affect the data. The presence of heteroskedasticity is checked with the likelihood-ratio test, while the test for serial correlation in the idiosyncratic errors of a linear panel-data model is done upon Wooldridge (2002) and Drukker (2003). The latter have shown that this test has good size and power properties in reasonable sample sizes.

The considerations above, as well as the "small-T and large-N" design of our panel, suggest the use of GMM to estimate the regression model (1) in Table 1.

In Model (1), the autocorrelation is examined using the Arellano-Bond, i.e. AR(1) and $\operatorname{AR}(2)$. Greater attention has been paid to the $\operatorname{AR}(2)$ test on the residual on first differences which is used to detect $\mathrm{AR}(1)$ in the underlying levels variables. The Arellano-Bond test for autocorrelation in the idiosyncratic disturbance term has the null hypothesis of no autocorrelation. In model (1), the test for AR (1) process in first differences rejects the null hypothesis, but the test for AR (2) in first differences, which is more important, because it detects autocorrelation in levels, does not reject it.

Two forms of the GMM estimator could be used here - the first difference- and the system- GMM. As also explained in other papers (Raileanu-Szeles, 2015), even though the system GMM usually increases efficiency, its use could be problematic especially when the dataset is rather small. This is because, first, the system GMM uses more instruments than the difference GMM, which could weaken the Sargan 
test. Moreover, our dataset is rather small, and if using the system GMM, the number of instruments would be greater than the number of countries. So, from this point of view, the difference GMM is preferred and therefore it is used in our paper.

If the endogeneity is not found in the data, in the presence of heteroskedasticity, the Generalized Least Squares (GLS) is the BLUE estimator. This is the case of models 2-6 in Tab.1 and Tab.2. In general, when the dependent variable has a subjective nature, the endogeneity is not suspected anymore, and the GMM estimator is not required anymore. In models (2)-(6), there is specified a heteroskedastic error structure with no cross-sectional correlation. Also, the regression models specify that, within panels, there is $\operatorname{AR}(1)$ autocorrelation and that the coefficient of the $\mathrm{AR}(1)$ process is specific to each panel. With these two specifications, our regression models take into account the heteroskedasticity across panels and autocorrelation within panels.

\section{Empirical Analysis}

In this section we apply the methodology previously described, e.g. panel data regression models, to underline the effects of two education variables on a group of economic and social variables. The latter are selected as to be indicative for the design of effective macroeconomic policies at the EU-27 level, and also to give insights to the economic development in the EU-27 area. A number of 6 panel regression models are run in Table 3 and Table 4 in order to examine the influence of a common set of explanatory variables on 3 indicators of quality of life, one indicator of economic growth, one indicator of poverty, and one indicator of institutional trust. The main idea of our empirical construct is to check whether the impact of explanatory variables is similar across all indicators of economic development, with a particular focus on the two education indicators.

Table 3 presents the impact of the secondary and tertiary education attainments, besides other economic and social determinants on three quality of life indicators: economic growth, confidence in the European Parliament and the self-evaluation of health status.

When being significant, the influence of most explanatory variables is relatively different across all dependent variables. Both the increase of tertiary education attainments and the increase of social protection expenditure determine the contraction of economic growth and the diminution of confidence in the European Parliament, as well as the decrease of population percentage reporting a bad health status. Increasing the secondary education attainments leads to the increase of confidence in the European Parliament, and also to the decrease of population rate reporting a bad health status. The coefficient of Gini variable suggests that a low level of social inequality determines the raise of confidence in the European Parliament, as well as the decrease of the population rate reporting a bad health status. 
Decreasing the unemployment rate and increasing the labour market policy expenditure represent the only policy measures able to improve all indicators of economic development in Models 1-3, i.e. the economic growth, the confidence in the European Parliament and the decrease of population rate reporting a bad health status.

Table 3: Determinants of quality of life indicators (part 1)

\begin{tabular}{|c|c|c|c|}
\hline Explanatory variables & $\begin{array}{l}\text { Model } 1 \\
\text { Dep: Economic } \\
\text { growth }\end{array}$ & $\begin{array}{l}\text { Model 2: } \\
\text { Dep: European } \\
\text { Parliament } \\
\text { confidence }\end{array}$ & $\begin{array}{l}\text { Model 3: } \\
\text { Dep: Bad health }\end{array}$ \\
\hline $\begin{array}{l}\text { Secondary education } \\
\text { L1 }\end{array}$ & $\begin{array}{l}-0.15(0.10) \\
0.12(0.10)\end{array}$ & $0.20 * * *(0.04)$ & $-0.09 * * *(0.01)$ \\
\hline $\begin{array}{l}\text { Tertiary education } \\
\text { L1 }\end{array}$ & $\begin{array}{l}-0.34 * *(0.16) \\
0.32 * *(0.15)\end{array}$ & $-0.26 * * *(0.05)$ & $-0.24 * * *(0.02)$ \\
\hline $\begin{array}{l}\text { Unemployment } \\
\text { L1 }\end{array}$ & $\begin{array}{l}-1.09 * * *(0.18) \\
1.18 * * *(0.22)\end{array}$ & $-0.28 *(0.17)$ & $0.27 * * *(0.04)$ \\
\hline $\begin{array}{l}\text { Gini } \\
\text { L1 } \\
\text { L2 }\end{array}$ & $\begin{array}{l}0.04(0.11) \\
0.16(0.12) \\
-0.09(0.13)\end{array}$ & $\begin{array}{l}-0.39 *(0.21) \\
-0.31(0.21) \\
-0.09(0.17)\end{array}$ & $\begin{array}{l}-0.05(0.05) \\
0.17 * * *(0.04) \\
0.01(0.04)\end{array}$ \\
\hline Social protection & $\begin{array}{l}-1.89 * * *(0.15) \\
1.61 * * *(0.15)\end{array}$ & $-1.05 * * *(0.13)$ & $-0.26 * * *(0.04)$ \\
\hline Expenditure labour & $0.99 * * *(0.26)$ & $3.36 * * *(0.09)$ & $-0.05(0.26)$ \\
\hline Constant & $4.76 * * *(1.86)$ & $101 * * *(5.8)$ & $19.8^{* * *}(1.98)$ \\
\hline
\end{tabular}

Notes: (1) Model 1: Dynamic panel regression model, Arellano-Bond one-step difference GMM estimator; Models 2-3: Cross-sectional time-series Feasible Generalized Least Squares (2) Model 1 ->Arellano-Bond test for AR(1) in first differences: $z=-2.14 \mathrm{Pr}>z=$ 0.032; Arellano-Bond test for AR(2) in first differences: $z=-0.16 \mathrm{Pr}>z=0.875$ (3)The standard errors are reported in brackets; (4) *** $p<0.01$, ** $p<0.05, * p<0.1$. (4) Models 1 3: 135-140 observations.

In Table 4, while the secondary education attainments carries a positive impact only on one out of three indicators of quality of life (i.e. the ability to face unexpected expenses), the tertiary education attainments positively influence all three indicators, i.e. it increases the ability to make ends meet, the ability to face unexpected expenses, and also it decreases the poverty risk. Unemployment is found to be the most powerful determinant of both, the inability to make ends meet and the inability to face unexpected expenses.

Both coefficients are positive in Models (4) and (5), which suggests that unemployment aggravates both subjective variables. Beside unemployment, the social inequality has a negative and significant impact on both the inability to make ends meet and the inability to face unexpected expenses, and additionally on the poverty risk as well. Its influence significantly and almost constantly lasts for at least two years (2 lags). 
The increase of social protection expenditure is harmful for the dependent variables in models (4)-(5), indicating that the raise of social spending does not contribute to the improvement of ability to make ends meet and the ability to face unexpected expenses. In turn, it enhances the reduction of poverty risk. In comparison with the social protection expenditure, the labour market policy expenditure determines the aggravation of all indicators of quality of life in models (4)-(6).

Table 4: Determinants of quality of life indicators (part 2)

\begin{tabular}{|l|l|l|l|}
\hline Explanatory variables & $\begin{array}{l}\text { Model 4: } \\
\text { Dep: Ends meet }\end{array}$ & $\begin{array}{l}\text { Model 5: } \\
\text { Dep: Unexpected } \\
\text { expenses }\end{array}$ & $\begin{array}{l}\text { Model 6: } \\
\text { Dep: Poverty risk }\end{array}$ \\
\hline $\begin{array}{l}\text { Secondary education } \\
\text { L1 }\end{array}$ & $0.09 * *(0.04)$ & $-0.39 * * *(0.04)$ & $0.029 * * *(0.05)$ \\
\hline $\begin{array}{l}\text { Tertiary education } \\
\text { L1 }\end{array}$ & $-0.75 * * *(0.09)$ & $-0.53 * * *(0.09)$ & $0.018(0.012)$ \\
\hline $\begin{array}{l}\text { Unemployment } \\
\text { L1 }\end{array}$ & $1.48^{* * *}(0.12)$ & $1.81 * * *(0.13)$ & $0.01(0.03)$ \\
\hline Gini & $0.47 * * *(0.11)$ & $0.31 *(0.17)$ & $0.54 * * *(0.04)$ \\
L1 & $0.14 *(0.08)$ & $-0.16(0.14)$ & $0.11^{* * *}(0.04)$ \\
L2 & $0.27 * * *(0.08)$ & $-0.32 * * *(0.12)$ & $0.09 * * *(0.03)$ \\
\hline Social protection & $-0.26^{* *}(0.11)$ & $-0.92 * * *(0.13)$ & $-0.11 * * *(0.03)$ \\
\hline Expenditure labour & $-3.33^{* * *}(0.80)$ & $-0.11(0.87)$ & $0.39 * *(0.17)$ \\
\hline Constant & $12.04 * * *(4.71)$ & $73.14 * * *(7.43)$ & $-5.69 * * *(1.51)$ \\
\hline
\end{tabular}

Notes: (1) Estimator: Cross-sectional time-series Feasible Generalized Least Squares (2) The standard errors are reported in brackets; (3) *** $p<0.01, * * p<0.05$, * $p<0.1$. (4) Models 1-3: 135-140 observations.

\section{Discussion and Conclusions}

The main objective of this paper was to investigate the effect of education and other potential drivers of economic growth on economic growth and also on a set of quality of life indicators. The results are contrasting to the literature, especially with regard to the education indicators. But these "surprising" results should be interpreted in the broader context given by the analysis of all explanatory variables together.

First, when being combined with the rest of explanatory variables reported in Tab. 1 and 2, the effects of the education variables are mixed across our set of dependent variables. The secondary education attainments have no significant effect on economic growth, while the tertiary education attainments carry a negative effect. In the literature, studies do not always find a positive of impact tertiary education on economic growth. The tertiary education has been found to generate an "antigrowth" effect (Birdsall et al., 1997; World Bank, 2000; Frankema, 2009).

Other papers relate this effect on the efficiency of public spending or the country's development level. For instance, Judson (1998) finds that the less efficient this 
expenditure distribution, the less gains in terms of GDP levels and growth. The effect of the tertiary education attainments on quality of life is a significant and positive one in models (4) and (5), as often underlined in the literature (Shamionov, 2014). This is because the higher education is associated to social status, goals reaching and finally to satisfaction with life. In turn, the effect of secondary education on the quality of life is mixed and unclear, according to our results.

In our paper, both education variables are found to generate positive effects on the self-rated health. This is in line with other studies that generally find that the higher the socio-economic status, the lower the prevalence of health problems (e.g. Bartley et al., 2004), and also with the studies conducted by the international organizations. The National Bureau of Economic Research states that "An additional four years of education lowers five-year mortality by 1.8 percentage points; it also reduces the risk of heart disease by 2.16 percentage points, and the risk of diabetes by 1.3 percentage points".

The social inequality has no significant impact on economic growth, but carries a negative and significant effect on the quality of life indicators and poverty risk. As expected, increasing the social protection expenditure leads to the improvement of quality of life (models 3-5) as well as the reduction of poverty risk, but in turn discourages economic growth. The redistribution and growth effects of social protection have been extensively discussed in the literature, being also confirmed by many empirical studies (Piachaud, 2013; Thalassinos and Pociovalisteanu, 2009). Therefore, increasing the social protection expenditure protects the poor and helps them actively involving in the economy. Sometimes, as it is our case, the price is the slowdown of economic growth due to the public spending pressure.

The labour market policy expenditure is aimed to enhance the labour market revival, which would further result in the acceleration of economic growth and improvement of the quality of life, through a better access to the labour market. These hypotheses are confirmed by our empirical results, so that this variable is one the most significant and powerful driver of both the economic growth and quality of life. In line with the literature and with the Okun's Law, unemployment is found to negatively influence both the economic growth and quality of life indicators. A particular matter of interest is to examine the drivers of the confidence in the European Parliament. The increase of secondary education attainments, reduction of income inequality, and especially the increase of labour market policy expenditure are likely to raise the general confidence in the European Parliament at the EU-27 level. This is particularly important for policy purposes at the EU-27 level.

When analysing the effects of all explanatory variables, it is evident that all of them involve divergent effects on the dependent variables. This lead to the main conclusion of our paper that it is very difficult targeting both the economic growth, the improvement of the quality of life, the decrease of poverty risk and the raise of 
confidence in the European Parliament, by national policy measures within the EU27 area. Our sample and set of variables indicated that increasing the labour market policy expenditure and reducing unemployment are the most effective policy measures that allow both the stimulation of economic growth and the improvement of the quality of life. The other policy measures request assuming a trade-off between the economic, politic and social aims. For instance, increasing the social protection expenditure and the tertiary education attainments determine the increase of quality of life, but reduce at the same time the economic growth and confidence in the European Parliament.

\section{References}

Bartley, M., Sacker, A., Clarke, P. 2004. Employment status, employment conditions, and limiting illness: Prospective evidence from the British household panel survey 1991-2001. J. Epidemiology Community Health, 58:501-506.

Birdsall, N., Ross, D. and Sabot, R. 1997. Education, Growth and Inequality. In Birdsall, N. and Jaspersen, F. (Eds.), Pathways to Growth. Comparing East Asia and Latin America, Inter-American Development Bank, Washington.

Drukker, D.M. 2003. Testing for serial correlation in linear panel-data models, Stata Journal, 3(2), 168-177.

European Commission. 2010. Communication from the Commission - Europe 2020, A Strategy for smart, sustainable and inclusive growth, Brussels, 3.3.2010 COM (2010) final.

European Commission. 2013. Education and Training Monitor 2013. ec.europa.eu/education/monitor

European Commission, Directorate General for Education and Culture. 2016. Study on the potential of education to cause macroeconomic imbalances and negative spillovers Final report.

Frankema, E. 2009. The expansion of mass education in twentieth century Latin America: a global comparative perspective. Revista de Historia Económica/ Journal of Iberian and Latin American Economic History, 27(03): 359-396.

Judson, R. 1998. Economic growth and investment in education: how allocation matters. Journal of Economic Growth, 3: 337-359.

National Bureau of Economic Research, http://www.nber.org/digest/mar07/w12352.html

Piachaud, D. 2013. Social protection, redistribution and economic growth, Development Southern Africa, 30(1), 24-38.

Raileanu- Szeles, M. 2015. Explaining the Dynamics and Drivers of Financial Well-Being in the European Union, Social Indicators Research, 120(3), 701-722.

Shamionov, R. 2014. Adaptational Potential and Subjective Well-being of Comprehensive School Graduates and First Year Students of Higher Educational Institutions, Procedia - Social and Behavioral Sciences, 131, 51-56.

Thalassinos, I.E. and Pociovalisteanu, M.D. 2009. The Structural Funds and the Economic and Social Cohesion Process. Annals-Economy Series 1, 313-330.

Wooldridge, J. M. 2002. Econometric Analysis of Cross Section and Panel Data. Cambridge, MA: MIT Press

World Bank. 2000. Higher Education in Developing Countries Peril and Promise. The task force on higher education and society. The International Bank for Reconstruction and Development, Washington. 